\title{
DEVELOPING ASKING AND GIVING INFORMATION MATERIALS DEALING WITH 2013 CURRICULUM OF SMP EIGHT GRADE
}

\author{
Nur Ilmiah \\ Universitas Islam Negeri Alauddin Makassar \\ nurilmiahridwan@gmail.com \\ Nur Aliyah Nur \\ Universitas Islam Negeri Alauddin Makassar \\ nuraliyahnur@uin-alauddin.ac.id
}

\begin{abstract}
This research aimed to develop an English material focusing on asking and giving information material based on 2013 curriculum of the Eight Grade Student at SMPN 2 Sungguminasa, Gowa. Based on the preliminary study on Mei 2016, the writer found that both the teacher and the students did not have appropriate and understandable materials. In addition, teacher on implementing the 2013 curriculum was unpreparedness and the students faced difficulties in learning English since they didn't have many sources except the students' book that provided by the government. This study utilized Research and development (R\&D), ADDIE Model (Analysis, Design, Development, Implementation, and Evaluation). This research started with the analysis the result of questionnaire which had been distributed to the students, then design English material based on syllabus and students need of the materials, it continued with the development of the materials, the product is going to be implemented in the real learning and teaching and the last is evaluation, one expert is involved to check the quality of the product. In this research, teacher and expert were involved in order to validate the product. There are two aspects that they validated of the product: Organization of the Materials and Content of English material. Overall, this research presented the product which content of lesson relevant with students need and curriculum. In addition, the product was expected to be able to help both the teachers and students in learning English especially about asking and giving information material.
\end{abstract}

Key words: Developing Materials, 2013 Curriculum, Eight Grade, ADDIE Model

\section{A. INTRODUCTION}

Purriculum is the most significant element which contributes to improve learnersabilityand potency (Richard, 2001:XI).Accordingly,curriculum that emphasizes competency is very crucial and needed.Such curriculum should become an instrument which guides learners to become: (1) qualified human beings who are able to face the challenge of time proactively; (2) educated human beings who are faithful, have piety toward the Lord, and have good morals, knowledgeable, creative, and self-directed;and (3) democratic and responsible citizens. Themplementation of competency-based curriculum is one of the strategies of national education building as stated by the Undang-undang Sisdiknas no 20 tahun 2003(Law 20 year 2003 on National Education System) (Ministry of Education and Culture, 2012, p. 3). 
Since 1947, the Indonesian government has created and implemented no less than ten different national curricula. The latest curriculum established earlier this year with Indonesia's new 2013 Curriculum. The improvement of 2013 Curriculum from "curriculum for each education unit" (Kurikulum Tingkat Satuan Pendidikan, abbreviated by KTSP), to "competency-based curriculum" according to Ministry of Education and Culture is reflecting some principles. Those principles are: (1) Curriculum must be designed by giving opportunity to learners to improve the differences in skill and interest; (2) Curriculum must be centered on potency, improvement, need, and benefit of learners and his environment. Curriculum must be designed based on the principle that learners is on central position and must be active while learning; (3) Curriculum must be perceptive to change of knowledge, culture, technology, and art; (4 Curriculum must be relevant with need of life (Sino-US English Teaching, August 2015).

Those reasons engage all of fields of subjects, including learning English. In the learning process, teachers hold a very crucial demand due to the fact that they will determine whether the learning objectives are accomplished or not and so does the student competency. However, teaching materials is one of the key components in teaching program, teachers are demanded to be able to select good teaching materials for their students, selecting materials determines the underlines content of lesson relevant with students need and curriculum.

According to the preliminary data outcome on May 2016 with the English teacher at SMPN 2 Sungguminasa Gowa who revealed that there are still many obstacles faced by teachers in implementing the 2013curriculum. First, the 2013 curriculum does not fit all schools for instance, uninadequate school assistance and different intakes of students such as, school in city is different from school in countryside. Second, the syllabus has a national principles so that the teacher does not have the authority to make their mark. Third, the lack of teachers' competence toward the implementation of the 2013curriculum. They do not have many specialized trainings dealing with it. Forth, both student and teacher book are not fully hellpful in teaching proces. Furthermore, the main point is the less of instructional media that support students' study. It is based on some reasons for instance, exercise is less varied and there is no specific skill rising in the learning materials. As a result, teacher needs an additional stuff in teaching it.

Therefore, designing English teaching materials in the form of coursebook is the pre eminent approach to conquer the irrelevant components on English teaching materials on the 2013 curriculum. Furthemore, this research develop English teaching materials according to 
Volume 4, Number 01, June 2018

the instructional materials and the lesson plans pass on the basic competences in the syllabus for the eight grade students of SMPN 2 Sungguminasa,Gowa. This case refers to basic competence 3.6 and 4.6 that discuss about asking and giving information. Hence, the writer formulates on study entitled "Developing Asking and Giving Information Materials Dealing with 2013 Curriculum of The EightGrade on SMPN 2 Sungguminasa, Gowa" for completing the teacher recent coursebook toward students' need.

\section{B. REVIEW OF RELATED LITERATURE}

\section{Previous of related findings}

Jacobson, Degener, and Gates(2003) conducted an R and D study to create authentic materials and activities for adult literacy classroom. In their study they have succeeded in the developing a textbook entitled "using and learning literacy and contexts" for adult learners focused on two different aspects of adult literacy instruction. The first was the nature of classroom activities and materials, and the second was the degree to which classes were collaborations between teachers and students. The study concluded that students who participated in classes the include authentic, or learner-contextualized, materials and activities were more likely to say they have started new literacy practices or had increase the amount of time spent and engaging in literacy activities outside of school. This was true event when the researcher controlled for (or accounted for ) students' literacy levels and the amount of time they had been attending class.

Tegeh and Kirna (2013) revealed that the purpose of the study determines into measure the development of teaching materials for educational research method by using ADDIE model and the results of trials of teaching materials of research method for education development. The model used sis the development of ADDIE Model (analyze, design, development, implementation, evaluation) because the research is the development of research. In the conclusion, the researchers say that the trial results showed individual instructional materials are in the qualification enough and the field test results indicate that well-qualified teaching materials.

Sukirman (Marshan, 2015) on his research "Developing English Morphology Course Material for undergraduate students" stated that most students are not interest and motivated to learn English Morphology as one of the most difficult courses and after identifying the problems and analyzing the factor. He design and develop English Morphology book as 
Nurilmiah, Nur Aliyah Nur, Developing Asking And Giving...

perfect as possible to build up students' motivation and stimulate them to be autonomous learners.

Limpo (2016) on his research Developing Descriptive Text Materials Dealing with 2013 Curriculum of the Seventh Grade in MTsN. Balang-Balang. In his research, he was created a course book as a handbook for students which contain a materials base on student's need.

Ali Mubar (Mubar, 2015) entitled "Developing English Learning Materials Based on Needs Analysis". The main objective of his research was to develop English speaking materials especially speaking as additional learning sources. He developed the materials based on the students' need and rule of Ministry of Education in 2006 number 22 about Kurikulum Tingkat SatuanPendidikan. Moreover it presents color full pages with many pictures and presenting local content for the students.

Almost all research about developing material use ADDIE model but the difference of this research with the other development research is the curriculum, this research use recent curriculum, and different material

\section{Some Pertinent Ideas}

\section{a. Concept of Materials Development}

According to Tomlinson (1998:2), material development is everything made by people (the writers, the teachers, or the learners) to give and utilize information and provide experience of the using language, which is designed to promote language learning. So, in developing materials they need to identify, first, learners' needs and consider the objective of the learning. Then, they can develop the materials by adapting them in order to improve or to make them more suitable to learners' needs. Adaptation can be carried out by reducing, adding, omitting, modifying, and supplementing learning materials.

\section{b. Asking and Giving Information Materials}

Asking and giving information material is one of the materials in 2013 Curriculum syllabus at the first semester of eight grade student. Those materials are include three subtopic, the first is using "there is" and "there are" second is neutral quantifier and the last is preposition.

The first subtopic is about using "there is" and "there are".

1) There is a library around the corner

2) There are two birds on the tree

3) There are a lot of students at the conference

4) There are some cake on the table 
Volume 4, Number 01, June 2018

5) There is a book in the room

The second subtopic is about neutral quantifier. The text structure as shown below:

1) There is not much tea

2) There is a lot of tea

3) There are not many apples

4) there are a lot of apples

The last subtopic is about preposition

1) the book is on the table

2) the hospital is beside the market

3) the bank is in front of the mosque talk about

c. Concept of 2013 Curriculum

In Modul Pelatihan Implementasi Kurikulum (2014: 4), the 2013 Curriculum is the development of curriculum with basic competence from the previous curriculum in KBK 2004 and KTSP 2006 which has attitude, knowledge, and skill. There are four competences for the 2013 Curriculum;

1) Kompetensi inti-1 (KI-1) for religious competence

2) Kompetensi inti-2 (KI-2) for social competence

3) Kompetensi inti-3 (KI-3) for cognitive competence

4) Kompetensi inti-4 (KI-4) for skill competence

\section{RESEARCH METHOD}

Research and Development method is the research method that is used to produce certain product and validate the product (Sugiono:2010). According to Sujadi (2003: 164) Research and Development is a process or steps to develop new product, or make product perfect which responsibility. From the definitions, the conclusion is Research and Development related with certain product. Developing a product using Addie's model is good enough. It because Addie's model has 5 steps that is quite enough to do.

Actually, Research and Development (R\&D) has many models, which can be applied by writer such as Sugiyono model, Addie model, Brog and Gall model, Dick and Carey model, Kemp model, and many others.

Based on many models stated formerly, this research applied ADDIE model. It develop by Florida State University to explain "the processes involved in the formulation of 
Nurilmiah, Nur Aliyah Nur, Developing Asking And Giving...

instructional System Development (ISD) program for military inter service training that will adequately train individuals to do a particular job and which can also be applied to any inter service curriculum development activity “. The model originally contained several steps under its five original steps (Analyse, Design, Development, Implementation and Development). The idea was to complete each step before moving to the next. Over the years, practitioners revised the steps, and eventually the model became more dynamic and interactive than the original hierarchical version. By the mid-1990s, the version familiar today appeared.

Finally, in this research applied ADDIE model because the model is very useful having stages clearly defined which makes implementation of instructions effectively. It strives to strive to save time and money by catching problems while they are still easy to fix. It also provides simple procedures to design and development materials.

\section{Development Models}

This research adopted ADDIE model. ADDIE is an acronym of Analysis, Design, Development, Implementation, and Evaluation. The procedures in developing deal with ADDIE model which provide five phases;

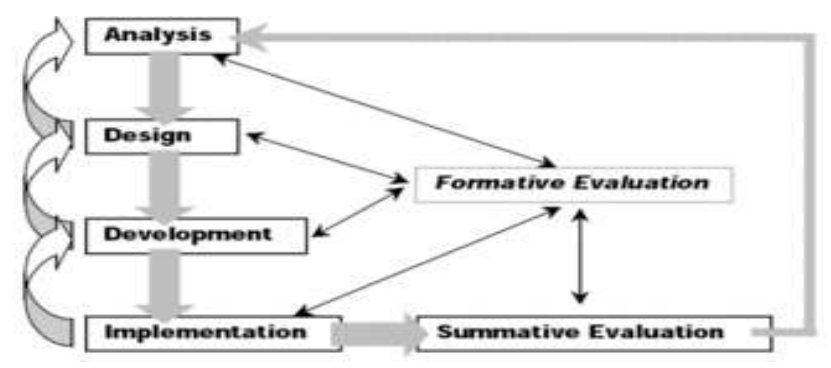

Figure 2.The ADDIE Model, Diagram by: Steven J. McGriff

\section{Analysis}

In analysis step, the result of questionnaire which has been distributed to the students previously analyzed qualitatively. Finally, this research was considered time and budget needed in this research. This phase is the most particular phases in ADDIE model because it is the basic for other phases of this model.

\section{Design}

In this phase design English materials dealing with 3.6 and 4.6 competences at 2013 curriculum while considering the goals and objectives of the learning process. First, the writer designed blueprint or materials frame work of the organization materials, learning materials, contents and assessment. Second, the writer identified as much as sources to guide the writer 
Volume 4, Number 01, June 2018

for designing English materials which is relevant with asking and giving information materials covered in the 3.6 and 4.6 competences.

\section{Development}

In this phase, developing the previous materials on the syllabus and produces the materials innovatively based on each of our own basic competence on the syllabus. Next, validate the product to the experts to make sure whether the product is appropriate to the learners' needs as well as the goals and the objective of the course or not. The final product is ready to be implemented in tryout activity.

\section{Implementation}

This phase deals with trying-out the product. The product is going to be implemented in the real learning and teaching by the writer. This phase also aims to know whether the product has fulfilled the objectives of course or not.

\section{Evaluation}

This phase was design to measure the rate of quality of the materials as being implemented. It was measure the appropriateness of the developing materials. In this evaluation, one expert is involved to check the quality of the product.

There are two types of evaluation. They are formative and Summative evaluation. Formative evaluation is ongoing during and between phases. It deals with the evaluation during the process of the materials development, whereas summative evaluation deals with the final evaluation of developed materials. It occurs after the final of materials implemented in trying-out the product (Marshan, 2015).

\section{FINDINGS AND DISCUSSION}

\section{Findings}

a. The result of content analysis of materials based on the syllabus

The result of content analysis based on the materials in the syllabus of 2013 Curriculum covering the 3.6 and 4.6basic competencies were expected to the students to able to asking and giving information about people, animals and things. First, the topic had been designed into 3 subtopics which appropriated with 4 meeting learnings. The first subtopic talk about how to use "there is" and "there are "in dialogue when we need to ask or give information. The second is how to use neutral quantifiers and the third is how to use preposition in asking and giving information about animals, people or things. Every meeting had a core skill thatwas integrated one another in flows of skill that were arranged sistematically. Again, 
Nurilmiah, Nur Aliyah Nur, Developing Asking And Giving...

learning activities deal with scientific approach included observing, questioning, collecting information, associating, and communicating. Last, the developed learning instruction referring to the type of activities is consisted of individual, pair, and group activitiy, the amount of activities, and text structure. These materials are developed in order to provide suitable materials for the eighth grade students of SMPN 2 Sungguminasa, Gowa.

b. The result of need analysis of developing learning materials based on the student's questioinaires

The questionaires consist of three parts. The first is systematic organization of integrated English materials. The secondis systematic English teaching which is appropriate with the learning activities and the systematic content of English materials covers the syllabus of the 2013 curriculum. After distributing the questionaires, in systematic organization of integrated English materials part, then the findings are conclude in this part into a table as shown below:

\begin{tabular}{|c|c|c|}
\hline Part & Focus & Conclusion \\
\hline$A$ & $\begin{array}{l}\text { Systematic } \\
\text { Organization }\end{array}$ & $\begin{array}{l}\text { all students wanted to be given the pre study-orientation } \\
\text { before studying. They wanted directly listen to the teacher's } \\
\text { explanation. The students were like if the materials were } \\
\text { given in drawing content and more like if the book was } \\
\text { designed with real-pictures as they saw in the daily life. }\end{array}$ \\
\hline$B$ & $\begin{array}{c}\text { Systematic English } \\
\text { Teaching }\end{array}$ & $\begin{array}{l}\text { If the materials talk about people around the students, they } \\
\text { would like to mention about their family or classmate. When } \\
\text { materials about animals they would like to talk about their } \\
\text { pat. Furthermore, they would like to make a list about things } \\
\text { around home, school, or class. However, when they were } \\
\text { asked to make a task, they would like to express it by write in } \\
\text { their own book. }\end{array}$ \\
\hline C & $\begin{array}{c}\text { Systematic content } \\
\text { of English } \\
\text { material }\end{array}$ & $\begin{array}{l}\text { Students were liked a learning model with discussion. They } \\
\text { also liked to do the project with a group, and when they } \\
\text { were asked to present a learning materials they would like to } \\
\text { present it with their partner, however students wanted the } \\
\text { teacher to combine the teaching process with "games } \\
\text { activity", and it was also found some obstacles that students } \\
\text { faced when they were learnt asking and giving information } \\
\text { materials 1) Students did not have many related } \\
\text { vocabularies, 2) Students were difficult to memorize a } \\
\text { dialogue and vocabulary, 3) Students were difficult to } \\
\text { translate the lesson into the source language, and 4) Students } \\
\text { were difficult to concentrate during the learning process. }\end{array}$ \\
\hline
\end{tabular}

Table 1 Result of questionnaire 
Volume 4, Number 01, June 2018

c. The result of need analysis of Expert judgment suggestion

The questionnaire that used by the researcher to analyze the students' needs ware originally designed. At the first time, it was designed by deciding the components that would be put on the questionnaire until it done with three parts. The first part consisted of six questions related to the organization of the materials, the point of the questions was to know the target of the materials systematic. Furthermore, in the second part that consisted of four questions related to the content of materials. These questions were pointed to know the learning systematic that the students' need in order to achieve the target in designing the materials that applicable for the students. Then, in the third part that consisted of five questions, the point of these questions was to know the target that wanted to achieve in systematic of learning materials.

Moreover, this questionnaire was not directly dealed out to the students. It was proposed to the expert to correct and to give suggestion according to the questionnaire made. Then, the expert was suggested to delete.

\section{Discussion}

On June 2013 the government started to implement 2013 curriculum. Many teachers still do not understand well about this curriculum because they do not have many specialized trainings dealing with it. As a consequence, the learning process is not running too well. Furthermore, it is needed a supporting materials which can help the students to understand the lessons.

The curriculum can be defined as set of education instrument which is used as a guide for the teachers on what and how to teach the students. Generally, the curriculum include all subject or activities which the school has responsibility to follow it in teaching and learning process.

The government has published a student book, but it is still not enough. The students need more. According to writer observation and interview with learners and teachers about the new coming curriculum, the 13 curriculum said that the book published by government still need to be improved. The book has essentially been good but the students need some addition activities and assignments which consist of skills in the learning materials. Besides that, the contents and activities in that book were not suitable with student's competence whereas individualized learning materials by direktoratpembinaansekolahmenengahatas said that the learning materials should be design based on students need. So, it entirely be cooperative in teaching process. On the other hands, teacher needs a stuff that can literally be 
a right tool in teaching. Many publishers have published their own book, but to opt for one proper book, we should consider many things, like;

1. Is the book appropriate for the students?

2. Has the book suitable with the 2013 curriculum?

3. Is the book covered students' need?

The main point is in the question number 3. There are so many books that has appropriate for the students based on their grade and suitable with the 2013 curriculum but for the book that has covered the students' need is literally limited and the way to provide the materials does not support their motivation to study. So, it cannot systematically enrich their skills in English especially in listening, speaking, reading, and writing. Hence, that is our primary reason on conducting this research. Developing new version of students' book truly got the writer's attention. Paying attention to what students' need becomes our very primary things to focus on to this research.

The newly developed product by the researcher is well qualified and can be used as a tool for learning due to it has been revised several times and tried out to the real teaching. Also, this product has been validated by experts which is being the primary aspect for creating a product.

\section{E. CONCLUSIONS}

Course book is common equipment in teaching English. Design the course book that relevant with 2013 curriculum will achieve the target learning. The materials which were developed should be considered what the students need to know and what the students want to achieve. The students hoped, their teacher can teach them well, Hence, the teacher should know how to developed the materials and more have good preparation.

Based on the result of the analysis of the questionnaire that distributed to the students in the eighth grade students at junior high school 2 Sungguminasa, Gowa where the aim of the questionnaire was to know the students' need in learning asking and giving information material and the product's outlook.

The result of the first research question is that to know the students' need on learning, it needs three stuffs. They are to identify the organization materials, the content materials, and the learning materials. In the oraganization materials, all students wish for the pre studyorientations before studying. They wanted directly listen to the teacher's explanation. The students resembled if the materials were given in drawing content and prefer cartoon and real 
picture design models they notice in the daily life. When it comes to the content materials, it consisted of two implies, i.e., the students opted for being provided a dialog that occur in their environment or had a dialog with their folk. They would like to be afforded a cartoon and real picture in design when learning material. Also, the students like accept the theory in learning material.

The result of the second reserch question is that creating a newly developed reference for the eight grade students on junior high school in learning English material. The product can be used as other reference in learning English for many considerations for instance, it was developed by first identifying students' need which became the foundation on developin this product, it is very colorful who fits the students' interest to build their attention on studying it, the material was developed in simplicity. It refers to the way the materials provided for students. It is easy to use and with clear instruction.

\section{REFERENCES}

Badan Pengembangan Sumber Daya Manusia dan Kebudayaan dan Penjamin Mutu endidikan Kementrian dan Kebudayaan (2014). Modul Pelatihan Implementasi Kurikulum. Jakarta: Badan Pengembangan Sumber Daya Manusia dan Kebudayaan dan Penjamin Mutu Pendidikan.

Direktorat Pembinaan Sekolah Menengah Atas Tahun (2008). Bahan ajar dan Jenis-jenis BAhan Ajar, in http://bahanajarpendidikan.blogspot.co.id/2016/07.Accesed on 30 Juli 2018.

Jacobson, E., Degener, S., \& Purcell-Gates, V. (2003).Creating authentic materials for the adult literacy classroom: A handbook for practitioners. Cambridge, MA: World Education, Inc.

J, Steven. (2000). ADDIE Model: Instructional Systems, College of Education.Penn State University. Available http://www.instructionaldesigncentral.com/htm/IDC_instructionaldesignmodels.ht m\#addie. Accessed on 17 January 201.

Kemendikbud. (2014). Modul Pelatihan Implementasi Kurikulum 2013. Jakarta: Badan Pengembangan Sumber Daya Manusia dan Kebudayaan dan Penjamin Mutu Pendidikan Kementrian dan Kebudayaan.

Limpo. (2016). Developing Descriptive Text Materials Dealing with 2013 Curriculum of the Seventh Grade in MTsN. Balang-Balang.

Miles, MB. \& Huberman, AM. (1994). Qualitative Data Analysis (2nd edition). Thousand Oaks, CA: Sage Publications.

Marshan, s. (2015). Developing English Morphology Materials for Undergraduate Students at Alauddin State Islamic University of Makassar. Eternal (english, teaching, learning, and research journal), 1(1), 1-14. 
Nurilmiah, Nur Aliyah Nur, Developing Asking And Giving...

Mubar, m. K. N. A. (2015). Developing English Learning Materials for Young Learners based on Needs Analysis at mtsn model makassar. Eternal (english, teaching, learning, and research journal), 1(2), 313-330.

Nurpahmi, S. (2013). An Introduction to English for Specific Purposes. Makassar: Alauddin University Press.

Nurpahmi, S. (2014). English for Specific Purposes: An Integrated Approach. Makassar: Alauddin University Press.

Nurpahmi, S. (2017). ESP Course Design: An Integrated Approach. Lentera Pendidikan: Jurnal Ilmu Tarbiyah Dan Keguruan, 19(2), 172-181. DOI:http://doi.org/1024252/lp.2016v19n2a4

Richards. (2001). Curriculum Development in Language Teaching. New York: Cambridge University Press.

Sugiyono. (2010). Metode Penelitian Pendidikan: Pendekatan Kuantitatif, Kualitatif, and R\&D. Bandung: Alfabeta. Cetakanke- 11.

Sujadi, (2003). Metodologi Penelitian Pendidikan. Jakarta. Rinekacipta

Tegeh and Kirna. (2013). Pengembangan Bahan Ajar Metode Penelitian Pendidikan dengan ADDIE Model. [e-journal]. 3. Available in:

Tomlinson, B. (2011). Materials Development in Language Teaching. United Kingdom: Cambridge University Press.

Thomas, David R. (2006). A General Inductive Approach for Analyzing Qualitative Evaluation Data. New Zealand: University of Auckland.

Undang-undangNomor 20 Tahun 2003. SistemPendidikanNasional.Pasal 35, ayat (1).

Yochanna, (2006) Choosing a course book, in http: //www .etni .org.il /etnirag/ issue4/ miri yochanna.htm.Accessed on 14 January 2017. 